\title{
Ogrody wertykalne jako efektowny element zieleni w krajobrazie zurbanizowanym
}

\author{
Magdalena Patro, Agnieszka Koper \\ Uniwersytet Przyrodniczy w Lublinie, Wydziat Inżynierii Produkcji, \\ Katedra Inżynierii Ksztaltowania Srodowiska i Geodezji, \\ e-mail:magdalenapatro@wp.pl,koper-agnieszka@o2.pl
}

Streszczenie: Zieleń jest integralnym i nieodzownym komponentem przestrzeni zurbanizowanej. Zapotrzebowanie na nią jest tym większe im większy jest stopień zabudowy danego miejsca. W przypadku braku możliwości wykorzystania powierzchni biologicznie czynnych do wprowadzenia roślinności lub chęci zabudowy mało estetycznych pionowych elementów krajobrazu miejskiego można zastosować ogrody wertykalne, których pomysłodawcą był Patrick Blanc w latach 80 . XX wieku. Możliwość wprowadzania wielkopowierzchniowych ogrodów nie zajmując powierzchni poziomych nasuwa nieograniczone możliwości bliskiego kontaktu z naturą w centrach wielkich miast, miejscach gęsto zasiedlonych, a nawet we wnętrzach budynków.

Praca ukazuje konsekwencje rozwoju budownictwa i infrastruktury miejskiej kosztem terenów zieleni oraz wskazuje ogrody wertykalne jako alternatywę dla kurczących się powierzchni zielonych. Przedstawia charakterystykę ogrodów wertykalnych, ich wpływ na krajobraz miejski oraz rozwiązania techniczne tych założeń. Głównym celem pracy jest prezentacja koncepcji ogrodu wertykalnego w przestrzeni miejskiej Lublina, z zastosowaniem filcowego systemu kieszeniowego, dla potrzeb poprawy walorów estetycznych miejsca oraz samopoczucia mieszkańców.

Słowa kluczowe: tereny zieleni, ogrody wertykalne, krajobraz zurbanizowany.

\section{Wstęp}

Wybuch demograficzny, który nastąpił po II wojnie światowej doprowadził do masowej urbanizacji przestrzeni. Krajobraz miejski charakteryzuje się dużą gęstością zabudowy, rozbudowaną infrastrukturą komunikacyjną oraz niskim poziomem estetycznym. Kontakt ze środowiskiem naturalnym w obecnych czasach jest dla człowieka szczególnie istotny. Mieszkańcy miast mogą odczuwać znaczny dyskomfort spowodowany brakiem obcowania z terenami otwartymi i zielenią.

Tereny zielone spełniają wiele funkcji pozytywnie wpływających na otoczenie oraz zdrowie człowieka. Przyrodnicze funkcje szaty roślinnej to głównie poprawa jakości powietrza przez oczyszczanie go z zanieczyszczeń i pochłanianie dwutlenku węgla, ale także tłumienie hałasu i kształtowanie klimatu. Roślinność spełnia również funkcje estetyczne i poprawia percepcję krajobrazu miejskiego. Dobrze wykorzystana potrafi zamaskować nieatrakcyjne elementy, a także podkreślić piękno architektonicznych brył. Zieleń w miastach jest także ostoją dla świata zwierzęcego. Zrównoważony rozwój miast powinien przedstawiać rozwiązania mające na celu połączenie tkanki miejskiej z terenami biologicznie czynnymi. Dzięki temu poprawi się funkcjonowanie układu urbanistycznego, środowiska przyrodniczego, a także zapewni komfort życia [1-2]. 
Wprowadzenie zieleni do ośrodków silnie zurbanizowanych jest jednak wyzwaniem dla projektantów i planistów. Rozwój miast i intensywność zabudowy sprawia, że coraz trudniej jest zagospodarować przestrzeń tak, by włączyć w nią tereny pokryte szatą roślinną. Zadania takie wymagają specjalnych technologii oraz odpowiedniego doboru gatunkowego. Tylko prawidłowo zaplanowane koncepcje mogą pozwolić na bytowanie roślinności w zgodzie z użytkowaniem terenu [3].

Celem pracy jest przedstawienie możliwości zwiększania zieleni w gęstej zabudowie miasta przez zastosowanie ogrodów wertykalnych oraz zaprezentowanie takiego rozwiązania w centrum Lublina i jego wpływ na walory estetyczne otoczenia i samopoczucie mieszkańców.

\section{Charakterystyka ogrodów wertykalnych}

\subsection{Historia ogrodów wertykalnych}

Wprowadzanie zieleni na budynki było znane już w starożytności. W Mezopotamii ponad 2500 lat temu wybudowano wiszące ogrody Babilonu, które znajdowały się na czterech tarasach podtrzymywanych na specjalnej konstrukcji złożonej z wąskich korytarzy. Wszystkie poziomy były wyposażone w sztuczne nawadnianie z izolacją bitumiczną oraz warstwą ziemi, gdzie sadzono krzewy i drzewa [4]. Kolejnymi naśladowcami byli Rzymianie, którzy uprawiali winorośl głównie przy kratach ogrodzenia lub bezpośrednio przy ścianach willi. Stosowano tam także pnące róże, będące symbolem tajnych ogrodów [5].

W dobie renesansu projektując ogrody wprowadzano formy żywych ścian w postaci żywopłotów. Wykorzystywano w nich gatunki takie jak cis, bukszpan, mirt. Barok zaś wyróżniał się okazałymi szpalerami z grabów i buków. Piętrzącą się roślinność wykorzystywano również jako element ozdobny przy pergolach i trejażach. Ideę pionowych ogrodów można także zauważyć w architektonicznych formach strzyżonych drzew i krzewów rozpowszechnionych w tej epoce. Przy rezydencjach pałacowych drzewa i krzewy posadzone tuż przy budynku prowadzone były tak by ich pędy pięły się po elewacji [6].

Na początku XX wieku zielone elewacje z pnączy, szczególnie z winobluszczu trójklapowego, stanowiły płynne przejścia pomiędzy ogrodem a domem. Dzięki swoim małym wymaganiom siedliskowym i odporności są idealnym rozwiązaniem dla małych przestrzeni $[7,8]$.

W 1995 r. w Japonii powstało założenie analogiczne do babilońskich ogrodów. Jego autorem jest Emilio Ambasz, który zaprojektował 15-kondygnacyjne Międzynarodowe Centrum Kultury i Informacji ACROS, zlokalizowane w mieście Fukuoka. Ściany pokryte zielenią tworzą spacerowe tarasy, które są naturalnym przedłużeniem parku. Ambasz zainteresował świat zieloną architekturą i niekonwencjonalnymi rozwiązaniami wprowadzania zieleni w obszarach silnie zurbanizowanych [9].

Prekursorem ogrodów wertykalnych jest Patrick Blanc, francuski naukowiec i botanik. Dzięki swoim licznym podróżom i zamiłowaniu do natury odkrył, iż na całym świecie istnieją gatunki roślin, które mogą wegetować w skrajnych warunkach. Patrick Blanc w 1988 r. opatentował rozwiązanie polegające na zaprojektowaniu roślin bez gleby w pozycji pionowej. Technologia oparta jest na filcowej tkance zastępującej glebę, która wchłania i retencjonuje wodę. Warstwa filcu przymocowana jest do płyty PCV specjalną siatką z elementami podtrzymującymi konstrukcję roślinną. Rośliny z czasem wrastają w warstwę fillcu. Całość założenia wyposaża się w system nawadniający, z którego woda odprowadzana jest do kanalizacji lub do powtórnego wykorzystania [6].

W Polsce pierwszy ogród wertykalny powstał w Gdyni na Bulwarze Nadmorskim. W ramach budowy nowatorskiego obserwatorium panele ogrodzenia placu budowy zastąpio- 
no ścianami zieleni o łącznej powierzchni około $30 \mathrm{~m}^{2}$. Nawiązują one kształtem oraz wzorem do modernistycznych trendów łącząc historię z nowoczesnym rozwojem miasta [10]. W Lublinie takie rozwiązanie można podziwiać na ścianie budynku Rektoratu Uniwersytetu Przyrodniczego w Lublinie (Fot. 1). Do przygotowania ogrodu o powierzchni $20 \mathrm{~m}^{2}$ wykorzystano 22 gatunki roślin. Instalacja oprócz walorów estetycznych pełni funkcje naukowe, m.in. określanie wytrzymałości roślin na zewnętrzne warunki atmosferyczne [11].

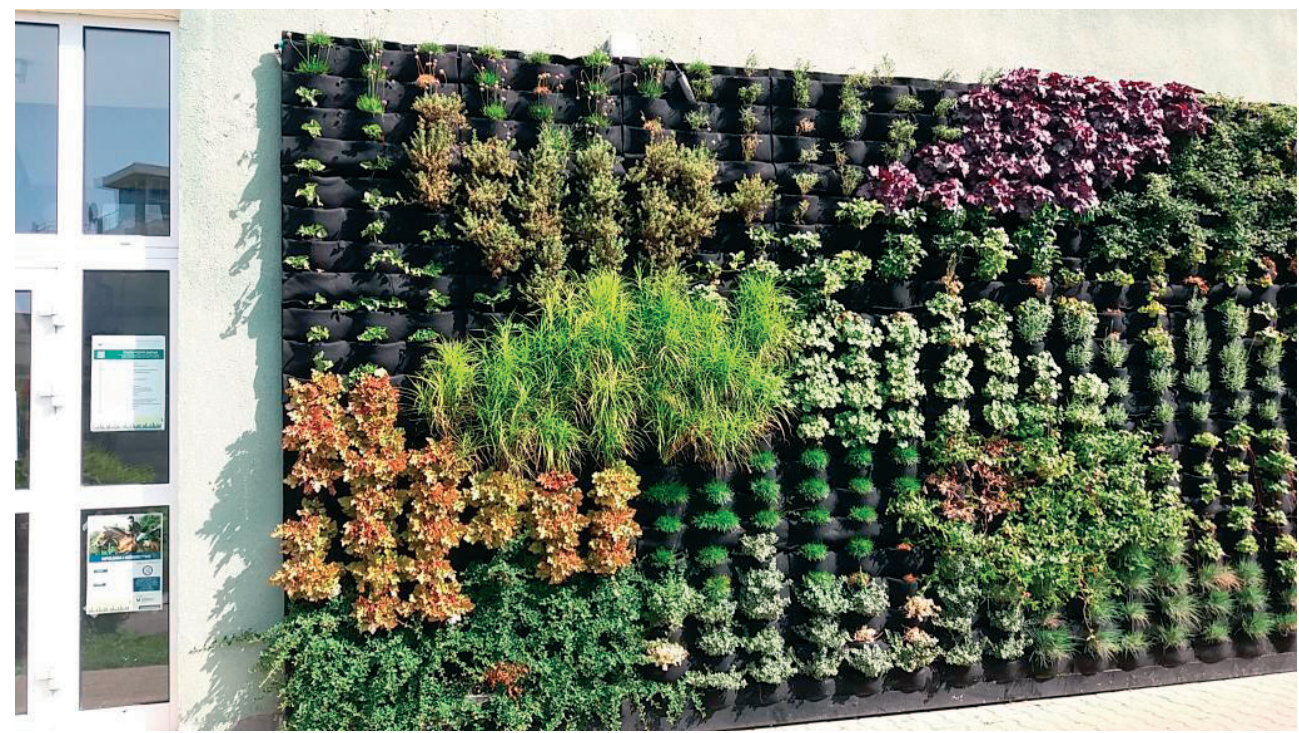

Fot. 1. Ogród wertykalny na ścianie Uniwersytetu Przyrodniczego w Lublinie (fot. M. Patro)

\subsection{Konstrukcja i systemy ogrodów wertykalnych}

Projektując ogród wertykalny należy uwzględnić kilka aspektów przyrodniczych i budowlanych. Do przyrodniczych należą: opady atmosferyczne, wiatr, pokrywa śnieżna oraz nasłonecznienie w okresie lata. Aspekt budowlany związany jest z analizą elewacji budynku, tj. wytrzymałością ścian na dodatkowe obciążenia oraz możliwości nośne całej ściany. W przypadku dużych założeń można stosować systemy zmniejszające ciężar całej konstrukcji przez wykonanie fundamentów [12].

Różnica w materiałach budowlanych, zmiany klimatu, zróżnicowane miejsca usytuowania wymusiły stworzenie różnych systemów, które umożliwiają zakładanie ogrodów w różnych miejscach, o różnej wysokości i kształcie. Istnieją trzy podstawowe systemy stosowane do zakładania zielonych ścian: system panelowy (modułowy), system filcowy (hydroponiczny) oraz system kontenerowy (Rys. 1).

System panelowy (modułowy). Popularna forma zakładania pionowych ogrodów, oparta na systemie paneli wykonanych z tworzyw sztucznych, stali nierdzewnej, aluminium i materiałów pochodzących $\mathrm{z}$ recyklingu. Panele te są łatwe w montażu, mocowane $\mathrm{z}$ niezależnych od siebie części, co ułatwia ich demontaż $\mathrm{w}$ razie konieczności. Celem tych modułów jest podtrzymanie korzeni i dostarczenie im substancji odżywczych. Większość rozwiązań zastępuje glebę perlitem, keramzytem, watą mineralną, matą z włókien kokosowych, mchem torfowym itp. [12].

System kieszeni filcowych. Jest to najprostszy w montażu system, składa się z: ramy (stanowiącej konstrukcję), płyty PCV (stanowiącej izolację między budynkiem a mokrym 
filcem) oraz mat wykonanych z włókien syntetycznych (przede wszystkim z filcu) (Fot. 2). Maty filcowe składają się z kieszeni, w których umieszczone są rośliny. Porowata struktura filcu pomaga roślinom w ukorzenianiu się, dostarczenia powietrza i wody [12].

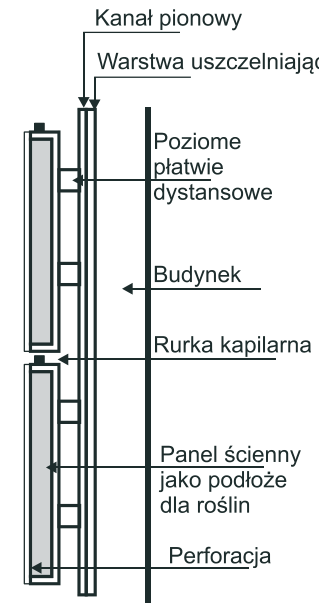

SYSTEM PANELOWY

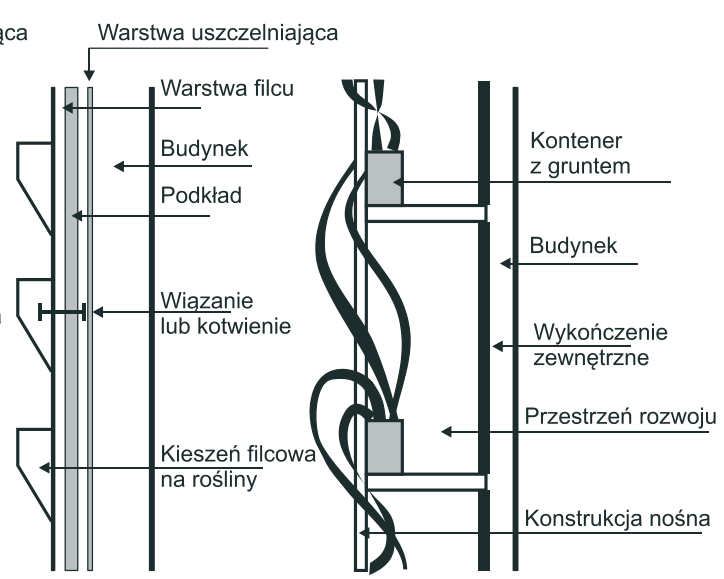

SYSTEM KONTENEROWY

Rys. 1. Systemy zakładania ogrodów wertykalnych [13]

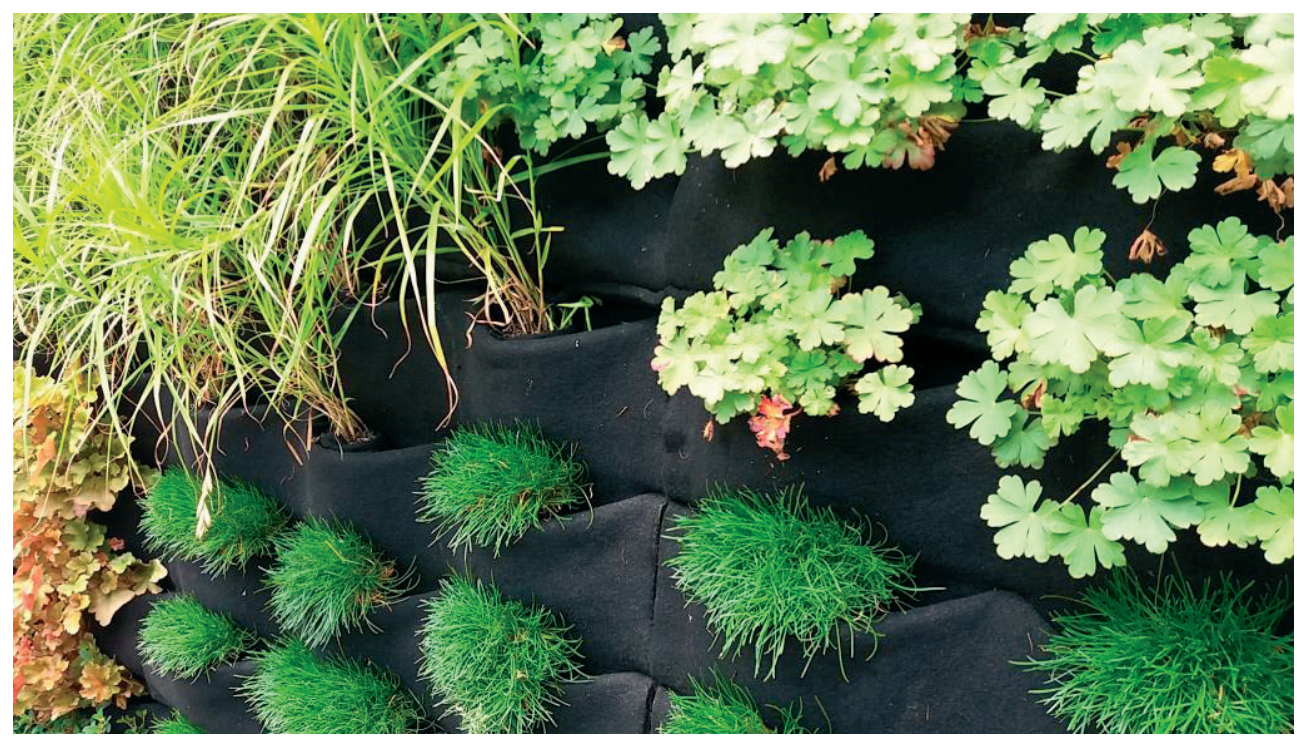

Fot. 2. Rośliny posadzone w filcowym systemie kieszeniowym (fot. M. Patro)

System kontenerowy. System rzadko stosowany, polegający na stworzeniu przestrzennej konstrukcji kratownicowej podzielonej na wiele poziomów, na których ustawiane są pojemniki z roślinami. Pojemniki wypełnione są odpowiednim podłożem, posiadającym zdolność magazynowania wody i substancji odżywczych. Wspinaczkę roślin umożliwia system stalowych lin lub siatek, z których można tworzyć proste lub bardziej skomplikowane formy. To rozwiązanie jest bardziej przestrzenne i zajmuje więcej miejsca niż systemy kieszeniowe i panelowe [12]. 
Tworząc koncepcję ogrodu wertykalnego należy zwrócić szczególną uwagę na dobór gatunkowy roślin. Przy doborze gatunkowym należy zwracać uwagę głównie na warunki klimatyczne. Zasadą w obsadzaniu ogrodu wertykalnego jest stosowanie większych gatunków roślin w wyższych partiach założenia, a mniejszych w niższych. W przypadku bezpośredniego sąsiedztwa ciągu pieszego należy stosować mniej ekspansywne rośliny. Chcąc uniknąć dysharmonii zestawienia gatunków należy zwrócić uwagę na charakterystyczne cechy każdej rośliny: gęstość, fakturę i kolor ulistnienia, sposób układania się pędów, rozmiary roślin, pokrój i kształt liści oraz kolor kwiatów. Ważnym elementem doboru gatunkowego są podobne wymagania siedliskowe roślin oraz niezbyt silny wzrost [14].

Przy ogrodach wertykalnych są stosowane różne podłoża, w których sadzi się rośliny [12]:

- substraty glebowe - ich struktura jest stabilna, przepuszczalna dla wody i powietrza;

- podłoża organiczne i nieorganiczne - najczęściej stosowane są maty z włókien kokosowych, torfu oraz specjalne wełny mineralne i geowłókniny; posiadają dobre właściwości chłonne;

- materiaty hydroponiczne - perlit, keramzyt, łupiny kokosowe - mają na celu stworzenie roślinom warunków zbliżonych do naturalnych oraz zapewniają dostęp do wody i składników odżywczych; zaletą jest oszczędne gospodarowanie wodą przez zamknięty jej obieg.

Nawadnianie ogrodów wertykalnych nie przysparza większych kłopotów. Zielone ściany najczęściej posiadają system samonawadniania, który dostarcza odpowiedniej ilości wody dla prawidłowego wzrostu roślin. Woda do nawadniania może być wzbogacona o składniki odżywcze, nawozy, minerały, aminokwasy, substancje usprawniające wzrost roślin [12].

\subsection{Wpływ ogrodów wertykalnych na krajobraz miejski}

Korzyści uzyskane przez zastosowanie ogrodów wertykalnych zależą od czynników konstrukcyjnych, zastosowanej roślinności (powierzchni i gęstości liści), warunków lokalnych i skali projektu. W krajobrazie zurbanizowanym wpływ ten może dotyczyć zarówno sfery publicznej jak i prywatnej.

W przypadku korzyści publicznych dotyczą one [15-17]:

- redukcji efektu miejskiej wyspy ciepła - poprawa naturalnych procesów chłodzenia, redukcja temperatury otoczenia, ocienianie powierzchni;

- poprawy jakości powietrza zewnętrznego - wychwytywanie zanieczyszczeń przez filtrowanie powietrza, osadzanie pyłów na powierzchni liści;

- poprawa estetyki - kreowanie panoram i widoków miast, przesłonięcie brzydkich powierzchni, zwiększanie cen nieruchomości, dostarczanie interesujących wolno stojących struktur.

Do korzyści w sferze prywatnej zaliczamy [15-17]:

- poprawa efektywności energetycznej budynków - zatrzymywanie warstwy powietrza w masie roślinności, ograniczanie ucieczki ciepła przez grubą warstwę roślinności, tworzenie strefy buforowej przeciwko wiatrowi;

- ochrona struktury budynku - ochrona zewnętrznego wykończenia przed promieniowaniem UV, wahaniami temperatury, zwiększanie szczelności otworów w przegrodach;

- poprawa jakości powietrza wewnętrznego - pochłanianie kurzu, pyłków i gazów szkodliwych;

- redukcja hałasu przez pochłanianie i odbijanie fal dźwiękowych. 


\section{Koncepcja ogrodu wertykalnego w przestrzeni miejskiej Lublina}

\subsection{Metodyka}

Koncepcję ogrodu wertykalnego wykonano dla ściany garażu w dzielnicy Wieniawa w Lublinie. W ramach prac przedprojektowych i projektowych wyróżniono:

- zapoznanie z uwarunkowaniami przyrodniczymi dla miasta Lublina, głównie z temperaturami powietrza i opadami atmosferycznymi;

- wykonanie niezbędnych pomiarów analizowanego obiektu;

- wykonanie niezbędnych analiz terenu (dendrologiczna, funkcjonalno-przestrzenna oraz kompozycyjno-widokowa);

- określenie wytycznych projektowych;

- wybór systemu ogrodu wertykalnego;

- dobór odpowiedniej roślinności.

\subsection{Rozwiązania techniczno-przyrodnicze}

Koncepcja dotyczy tylnej ściany garażu, stanowiącej bezpośredni widok z okien nowo wybudowanego bloku przy ulicy Leszczyńskiego (Fot. 3). Koncepcja zakłada wprowadzenie ogrodu wertykalnego, który ma na celu przysłonięcie nieatrakcyjnej i monotonnej ściany garażu oraz zapewnienie miłego widoku z okien mieszkańcom nowego budynku mieszkalnego.

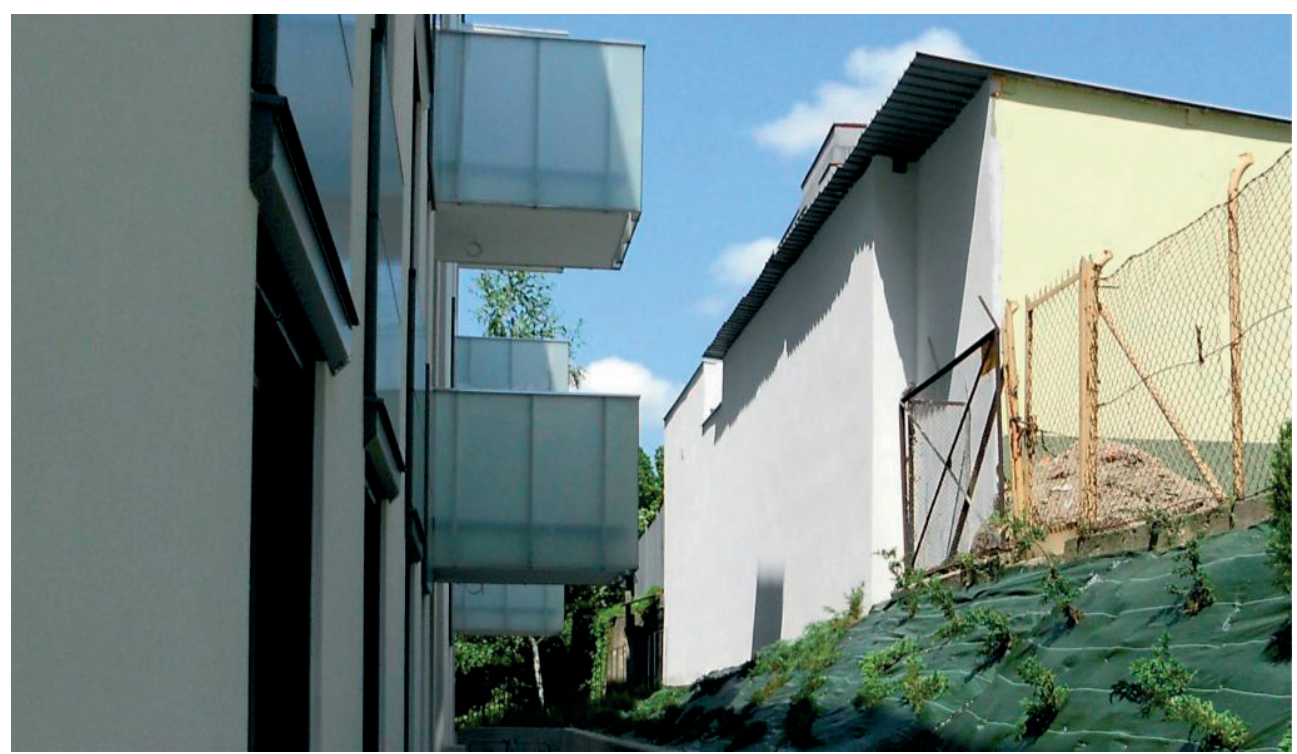

Fot. 3. Omawiana ściana garażu (fot. A. Koper)

Analiza obiektu. Teren opracowania leży w ścisłej zabudowie mieszkaniowej wielorodzinnej oraz sąsiaduje z zabudową biurową, oświatową i sądem. Obszary towarzyszące zabudowie to głównie parkingi i chodniki. Na analizowanym obszarze można wyróżnić wnętrze urbanistycznie podłużne, które wyznacza elewacja budynku mieszkalnego oraz ściana garażu. Lokatorzy parteru i pierwszego piętra mają bezpośredni widok na ścianę garażu, która znajduje się tak blisko budynku mieszkalnego $(3,7 \mathrm{~m})$, że domownicy nie mają możliwości obserwacji otoczenia za nim. 
U podnóża ściany garażu znajduje się skarpa zabezpieczona betonowym murkiem. Obsadzona jest głównie płożącą roślinnością iglastą (jałowiec płożący Juniperus horizontalis, jałowiec łuskowaty Juniperus squamata, cyprysik groszkowy Chamaecyparis pisifera) z czarną geowłókniną okrywającą glebę. Przejście między budynkiem mieszkalnym a murkiem oporowym, dostępne głównie dla mieszkańców mających bezpośrednie wyjście z mieszkań przez drzwi balkonowe, wykonane jest z kostki betonowej w kolorze szarym.

Konstrukcja ogrodu wertykalnego. Ściana będąca podstawą projektową posiada wystawę zachodnią, gdzie ilość promieni słonecznych docierających do niej jest ograniczona przez budynek mieszkalny. Głównym punktem założenia jest zaprojektowanie ogrodu wertykalnego z elementami drewna, betonu i pnączami po obu stronach ogrodu, prowadzonymi po stalowych linach. Wkomponowane elementy paneli drewnianych mają być akcentem ocieplającym i przełamującym bladość ściany i otoczenia, zaś elementy betonowe nawiązywać do materiału budulcowego murka oporowego u podnóża ściany (Rys. 2).

Starając się odciążyć ścianę garażu całość ogrodu zbudowano z lekkich paneli z kieszeniami filcowymi firmy Florafelt. Panele zostały zawieszone na metalowym stelażu wykonanym z rur kwadratowych o przekroju 40x40 mm, wspartym na fundamencie oraz przytwierdzonym do ściany garażu, co poprawia jego sztywność i nośność. Całość konstrukcji ma długość 10,5 m i wysokość $3 \mathrm{~m}$. Tak zaprojektowany ogród wertykalny nie wpływa na trwałość i obciążenie ściany garażu.

Nasadzenia roślinne. Zastosowana roślinność została dobrana przede wszystkim pod względem mrozoodporności, niewielkich rozmiarów (maksymalnie 30-40 cm wysokości), dekoracyjności (głównie z liści), niewielkiej ekspansywności oraz podobnych wymagań środowiskowych (Tab. 1, Rys. 2-4). Rośliny nie wymagają tradycyjnego podłoża lub innych substratów. Należy pozostawić roślinie podłoże, w którym została zakupiona, a bryłę korzeniową owinąć w filc wyposażony w podsypkę z perlitu. Całość związujemy gumką i umieszczany w kieszeni na właściwym miejscu. Różna kolorystyka liści, zróżnicowany pokrój zastosowanych roślin oraz wkomponowanie ogrodu wertykalnego w gęsto zabudowany krajobraz miejski powoduje poprawę wrażeń wizualnych (Rys. 3-4).

System nawadniania. Zaprojektowano linię nawadniającą poprowadzoną rurą pionowo w górę. Na szczycie znajduje się rura z otworami, przez które sączy się woda z rozpuszczonymi składnikami odżywczymi. Ciecz przesiąka grawitacyjnie w dół konstrukcji dostarczając wszystkim roślinom jednakową dawkę wody i składników odżywczych przez doskonałą zdolność filcu do pobierania wody. Nadmiar wody skrapla się do specjalnie wydrążonego rowka w gruncie skarpy (gł. $10 \mathrm{~cm}$ ), wypełnionego żwirem o średnicy 16/32 mm. Rowek znajduje się dokładnie pod konstrukcją, przez co pozwala na przechwycenie wody spływającej z ogrodu wertykalnego oraz wsiąkanie jej do wnętrza skarpy dostarczając niewykorzystaną pożywkę z wodą roślinom, którymi obsadzona jest skarpa.

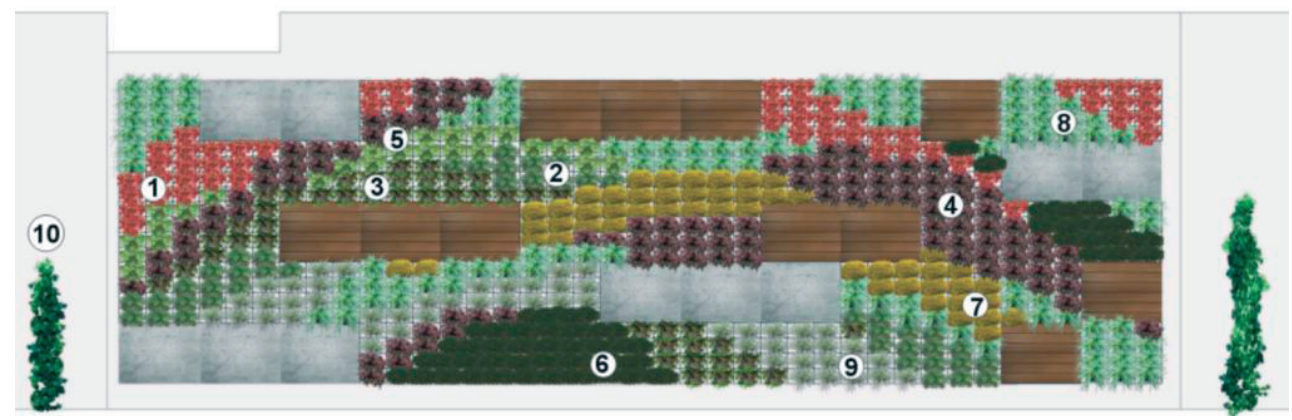

Rys. 2. Koncepcja ogrodu wertykalnego na ścianie garażu - numeracja roślin zgodna z Tab. 1 


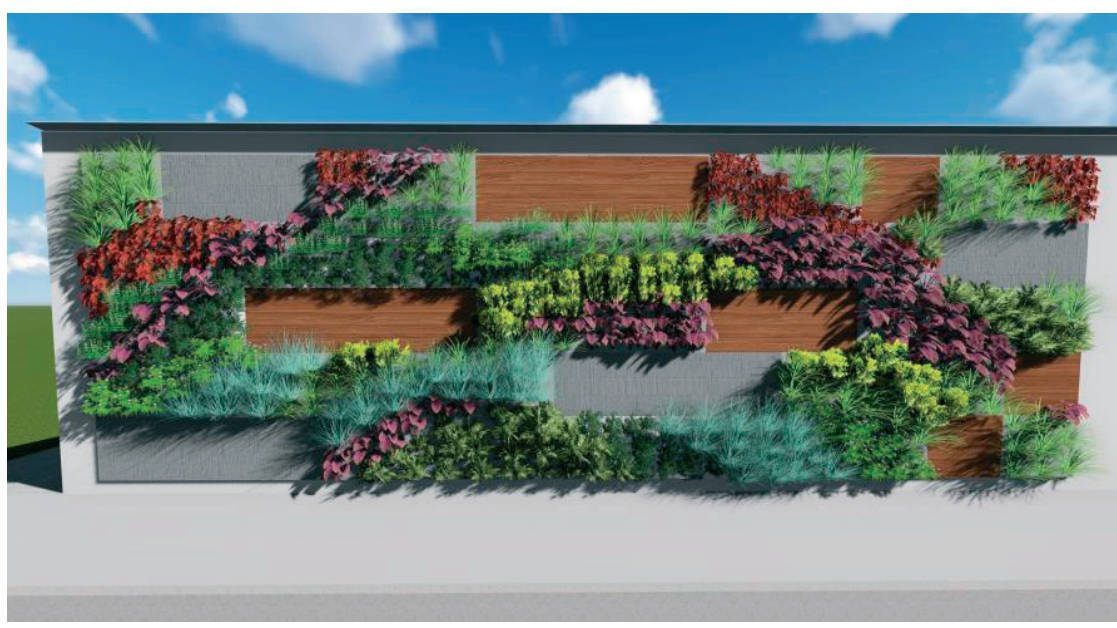

Rys. 3. Widok ogrodu wertykalnego na ścianie garażu - wizualizacja

Tabela 1. Spis roślin do obsadzenia ogrodu wertykalnego

\begin{tabular}{lll}
\hline Lp. & Nazwa łacińska & Nazwa polska \\
\hline \multicolumn{1}{l}{ BYLINY } & \\
\hline 1 & Epimedium x rubrum & Epimedium czerwone \\
2 & Geranium macrorhizm & Bodziszek korzeniasty \\
3 & Glechoma hederacea & Bluszczyk kurdybanek \\
4 & Heuchera hybrida & Zurawka ogrodowa \\
5 & Pachysandra terminalis & Runianka japońka \\
\hline KRZEWY & \\
\hline 6 & Cotoneaster dammeri 'Major' & Irga Dammera 'Major' \\
7 & Spiraea japonica 'Golden Carpet' & Tawuła japońska 'Golden Carpet' \\
\hline TRAWY & \\
\hline 8 & Carex ornithopoda & Turzyca ptasie łapki \\
9 & Holcus mollis & Kłosówka miękka \\
\hline PNACCZA & \\
\hline 10 & Hedera helix & Bluszcz pospolity \\
\hline
\end{tabular}

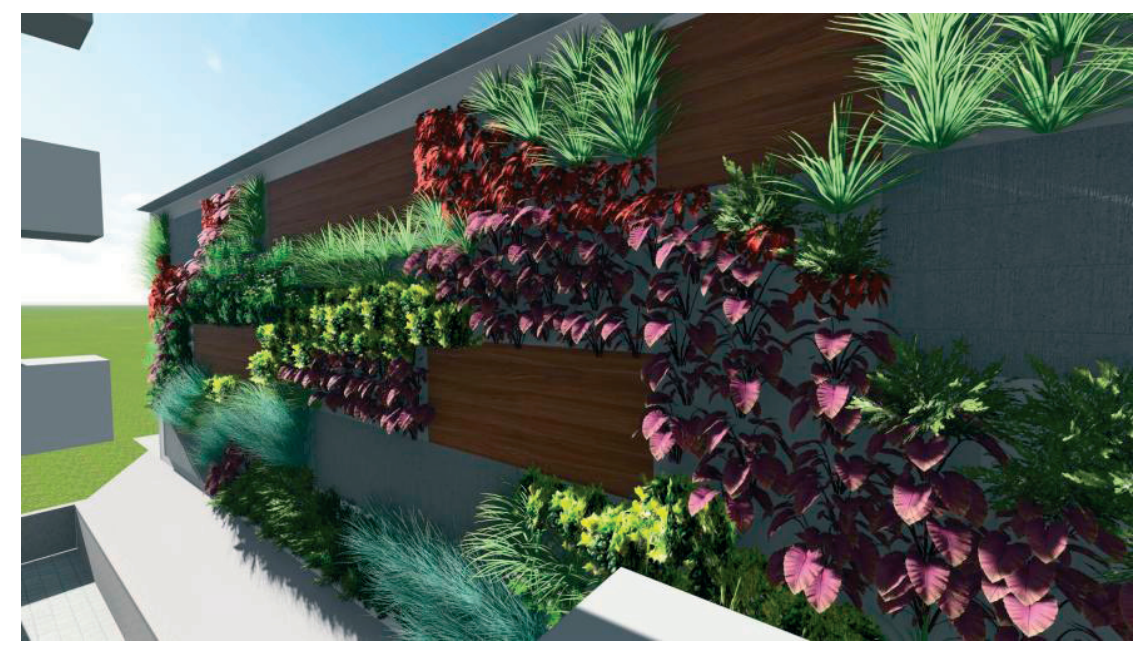

Rys. 4. Widok na ścianę garażu zabudowaną ogrodem wertykalnym - wizualizacja 


\section{Podsumowanie}

Obecnie istnieje wiele rozwiązań pozwalających na wprowadzenie zieleni do przestrzeni o zwartej zabudowie. Powierzchnie utwardzone mogą zostać wyposażone w pojemniki oraz donice $\mathrm{z}$ roślinnością. Takie metody są szczególnie wskazane w miejscach występowania gęstej sieci podziemnej infrastruktury technicznej. Kolejną możliwością są pnącza, które mogą stanowić pionową formę zielonej dekoracji. Jednak to ogrody wertykalne, poprzez wielobarwne kompozycje roślin o rozmaitych fakturach, wywołują silne bodźce wizualne. Dzięki innowacyjnym technologiom pozwalają na coraz śmielsze realizacje będące dopełnieniem ścisłej zabudowy architektonicznej. Ogród wertykalny może być narzędziem, które pozwoli zamienić nagą ścianę w kwitnący ogród i tym samym stać się oazą bioróżnorodności. To również sposób na dostarczenie mieszkańcom miast dawki natury niezbędnej do zdrowego i komfortowego życia. Ogrody wertykalne są swego rodzaju dziełami sztuki, które mają swój pozytywny udział w kształtowaniu estetycznego wizerunku miasta.

Przedstawiona w artykule koncepcja ogrodu wertykalnego na nieatrakcyjnej ścianie garażu w centrum miasta Lublina zapewni miły widok $\mathrm{z}$ okien mieszkańcom nowego budynku mieszkalnego. Przedstawiony projekt wykorzystuje system lekkich paneli kieszeniowych, wypełnionych roślinami charakteryzującymi się mrozoodpornością, niedużym wzrostem, dekoracyjnymi liśćmi oraz różnorodnością kolorystyczną, która wprowadza dynamizm i zachęca do obserwacji. Ponadto zaproponowany ogród wertykalny stanowi nietuzinkowe rozwiązanie poprawy walorów monotonnego krajobrazu zurbanizowanego będąc jednocześnie naturalną formą wyrazu artystycznego.

\section{Literatura}

1. Haber Z. Ksztaltowanie terenów zieleni z elementami ekologii. Wyd. Akademii Rolniczej, Poznań, 2001.

2. Orzeszek-Gajewska B. Kształtowanie terenów zieleni w miastach. Wyd. PWN, Warszawa, 1984.

3. Chojnacka M., Wilkaniec A. Problemy projektowe zwiąane z zielenia towarzyszaca współczesnej zabudowie miejskiej. [w:] Techniki i technologie dla terenów zieleni (red. Drozdek M.). Oficyna Wyd. PWSZ, Sulechów, (2009) 45-55.

4. Kasińska L., Sieniawska-Kuras A. Architektura krajobrazu dla każdego. Wyd. KaBe, Krosno, 2009.

5. Majdecki L. Historia ogrodów. Tom 1. Od starożytności po barok. Wyd. PWN, Warszawa, 2009.

6. Kosiński W. Pionowe ogrody - Idea, Technologia i Estetyka na Nowy Wiek. Architektura. Czasopismo techniczne 2-A/2 (2011) 105-125.

7. Łączyńska M. Pnacza moga wiele. Ogrody, ogródki, zieleńce 3 (2011) 18-20.

8. Trzaskowska E. Wykorzystanie roślin w projektowaniu architektonicznym (pnacza, ogrody wertykalne). Teka Kom. Arch. Urb. Stud. Krajobr. - OL PAN, (2010) 110-121.

9. Wines J. Zielona architektura. TASCHEN, Koln, Germany, 2008.

10. http://zielonesciany.pl/pl/infobox-gdynia, (08.07.2016)

11. http://www.up.lublin.pl/glowna/?form=default\&rid=7062, $(08.07 .2016)$

12. Tkaczyk T., Karczmarczyk I., Nowacki Ł., Haraszczuk K., Gawroński G., Marczewski S. Miasto zielone z natury. Agencja Create Event, 2014.

13. Ksit B., Majcherek M. Green Walls, czyli zielone ściany jako ekologiczne przegrody budowlane. Inżynier budownictwa 6(107) (2013) 120-122. 
14. Kania A., Mioduszewska M., Płonka P., Rabińska J.A., Skarżyński D., Walter E., WeberSiwirska M. Zasady projektowania $i$ wykonywania zielonych dachów $i$ żyjących ścian. Poradnik dla gmin. Agencja Reklamowo-Wydawnicza „Ostoja”, Kraków, 2013.

15. Green Roofs for Healthy Cities: Introduction to Green Walls 2008 (www.greenroofs.org)., (15.05.2016)

16. Majerska-Pałubicka B. Powierzchnie biologicznie czynne jako element przegród budowlanych. Architektura. Czasopismo techniczne 2-A/2 (2011) 153-160.

17. Trzaskowska E., Adamiec P. Rola roślinności w ksztattowaniu panoram i widoków miasta. Teka Kom. Arch. Urb. Stud. Krajobr. - OL PAN (2010) 122-132.

\title{
Vertical gardens as an eye-catching element of greenery in urban landscape
}

\author{
Magdalena Patro, Agnieszka Koper \\ University of Life Sciences in Lublin, Faculty of Production Engineering, \\ Department of Environmental Engineering and Geodesy, \\ e-mail:magdalenapatro@wp.pl,koper-agnieszka@o2.pl
}

\begin{abstract}
Greenery is an integral and an indispensable component of the urban space. The greater the degree of development of the site is, the greater the demand for greenery is. In the case of lack of using of biologically active surface to introduce vegetation or willingness to build-up (hide) little aesthetic vertical elements of the urban landscape, vertical gardens can be used. They were conceived by Patrick Blanc in the 80 s of XX century. The possibility of the introduction of large gardens without taking horizontal surfaces suggests endless possibilities of close contact with nature in the centres of large cities, densely populated areas and even inside buildings.

The paper shows the consequences of the development of housing and urban infrastructure at the expense of green areas and indicates vertical gardens as an alternative to shrinking green spaces. The characteristics of vertical gardens, their impact on the urban landscape and the technical solutions of these assumptions were shown. The main aim of this paper is to present the concept of a vertical garden in the city of Lublin, using a system with felt pockets, for the purpose of improving the aesthetic of the space and well-being of inhabitants.
\end{abstract}

Keywords: green areas, vertical gardens, urban landscape. 